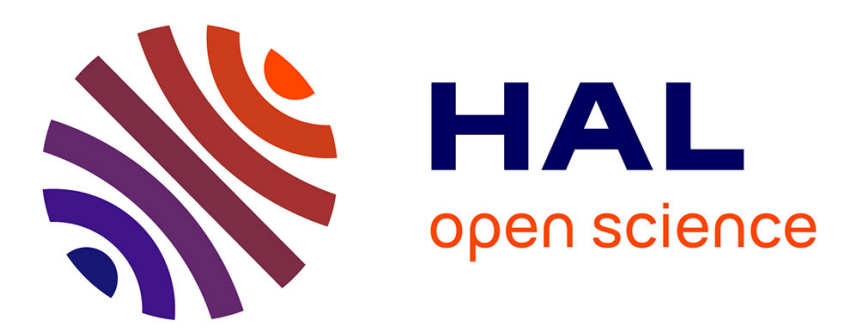

\title{
Changes in species assemblages and diets of Collembola along a gradient of metal pollution
}

Servane Gillet, Jean-François Ponge

\section{To cite this version:}

Servane Gillet, Jean-François Ponge. Changes in species assemblages and diets of Collembola along a gradient of metal pollution. Applied Soil Ecology, 2003, 22 (2), pp.127-138. 10.1016/S09291393(02)00134-8 . hal-00498546

\section{HAL Id: hal-00498546 https://hal.science/hal-00498546}

Submitted on 7 Jul 2010

HAL is a multi-disciplinary open access archive for the deposit and dissemination of scientific research documents, whether they are published or not. The documents may come from teaching and research institutions in France or abroad, or from public or private research centers.
L'archive ouverte pluridisciplinaire HAL, est destinée au dépôt et à la diffusion de documents scientifiques de niveau recherche, publiés ou non, émanant des établissements d'enseignement et de recherche français ou étrangers, des laboratoires publics ou privés. 


\title{
Changes in species assemblages and diets of Collembola along a gradient of metal pollution
}

\author{
Servane Gillet, Jean-François Ponge* \\ Museum National d'Histoire Naturelle, CNRS UMR 8571, 4 avenue du Petit-Chateau, 91800 Brunoy,
}

France

\begin{abstract}
Springtails (Hexapoda: Collembola) are known to live in a wide range of soil conditions, but changes occurring in their communities under the influence of heavy metal pollution are still poorly documented. The present study was undertaken in order to discern main coenological trends along a gradient of metal pollution, downwind of a zinc smelter located in the North of France. Three sites were compared within an abandoned field planted with poplar twenty years ago. The total zinc content of the topsoil varied from 4000 to $35000 \mathrm{mg} / \mathrm{kg}$ according to distance to the smelter outlet. Changes in humus forms (shift from mull to mor) and in the degree of opening of the poplar stand (mainly caused by death or stunting of planted trees in the vicinity of the smelter) explained most of the observed variation in abundance and species composition. Sun species living at the ground surface appeared at the most polluted sites where poplar declined and was replaced by a sward of metal-tolerant herb species. The increase in abundance of the whole collembolan community was mainly due to Mesaphorura macrochaeta, the gut contents of which indicated that this species avoided the root mat and fed mainly in the mineral soil underneath. Shifts in food habits and/or in habitat were observed in several other common species, pointing to the importance of avoidance behaviour as a mechanism by which collembolan species may endure heavy metal pollution.
\end{abstract}

Keywords: Collembolan communities, Heavy metals, Gut contents

\section{Introduction}

\footnotetext{
"Corresponding author. Tel.: +33 1 60479213; fax: +33 1 60465009; E-mail: jeanfrancois.ponge@wanadoo.fr
} 
Pollution by heavy metals, due to smelter, mining or agricultural activity, has been shown to adversely affect soil animal communities (Bengtsson and Rundgren, 1988; Hågvar and Abrahamsen, 1990; Bruus Pedersen et al., 1999). Direct toxicity of heavy metals to soil animals has been demonstrated (Tranvik et al., 1993; Crommentuijn et al., 1997; Scott-Fordsmand et al., 1999) and it is likely that changes in habitat and food resources affect soil animal communities, too. Toxicity to decomposer microbes and animals is indicated by a drastic reduction in litter decomposition rate and pronounced changes in humus forms from mull to mor (Coughtrey et al., 1979; Bengtsson et al., 1988a; Gillet and Ponge, 2002). Above a given threshold of heavy metal contamination, the impairment of decomposer activity creates a new habitat which may affect the abundance, diversity and species composition of soil animal communities, even when the critical load of heavy metals is not reached by individual species. Some soil animal species may also resist heavy metal contamination by selecting less-contaminated micro-sites (Tranvik and Eijsackers, 1989; Bengtsson et al., 1994a) or by changing their reproductive, excretory or feeding behaviour (Joosse and Buker, 1979; Bengtsson et al., 1985; Niklasson et al., 2000).

We decided to test the hypothesis that soil animal communities sampled along a gradient of heavy metal pollution show a) shifts in species composition, b) shifts in food habits of tolerant species, and that these changes can be explained, at least partly, by associated changes in humus form and vegetation. Springtails (Hexapoda: Collembola) were chosen as test animals given their abundance and diversity in a wide variety of soil types (Ponge, 1993; Petersen, 1994; Ponge et al., 1997), the flexibility of their alimentary habits (McMillan, 1975; Hasegawa and Takeda, 1995; Ponge, 2000a), and strong variation among species in sensitivity to heavy metals (Bengtsson and Rundgren, 1988; Bruus Pedersen et al., 1999; Filser et al., 2000).

\section{Materials and methods}

\subsection{Study sites}

The Bois des Asturies in Auby (Nord, France) is near to and downwind of a zinc smelter which is one of the largest in the world (producing 245000 tons of zinc per year). The wood today suffers from 
active pollution by heavy metals, mainly $\mathrm{Zn}$, but $\mathrm{Cd}$ and $\mathrm{Pb}$ are present in the soil from past activity. This site was formerly used to deposit slag rich in heavy metals. Hybrid poplar (Populus sp.) was planted in 1974 and 1977 on the site most remote from the smelter and in 1981 and 1983 nearer the smelter, after a change in production methods when electrolysis replaced coal burning. The plantation becomes sparser nearer to the smelter, due to the death of most trees, and surviving trees are stunted. A sward of plants tolerant to heavy metals such as Viola calaminaria, Armeria maritima halleri, Arrhenaterum elatius and Cardaminopsis halleri covers the ground.

Three sites were studied. Site P1, $490 \mathrm{~m}$ from the smelter, is characterized by a field layer with A. elatius and $C$. halleri as dominant species, under a closed poplar canopy. Site P2, $340 \mathrm{~m}$ from the smelter, has a dense cover of $V$. calaminaria under an incomplete poplar canopy. There is no poplar at site P3, nearest the smelter $(235 \mathrm{~m})$, and the field layer is dominated by $A$. maritima halleri and Phragmites australis.

The soil is a silty clay loam, but the top 10 centimetres are mainly organic matter, humified and partly mixed with mineral matter at P1, but undecayed at P2 and P3 (Gillet and Ponge, 2002). Litter horizons, according to the nomenclature of O horizons by Brêthes et al. (1995) and Ponge et al. (2000), are OL $(1.5 \mathrm{~cm})$ and $\mathrm{OF}(1.5 \mathrm{~cm})$ at $\mathrm{P} 1, \mathrm{OL}(2 \mathrm{~cm})$ and $\mathrm{OM}(7 \mathrm{~cm})$ at $\mathrm{P} 2, \mathrm{OL}(1 \mathrm{~cm})$ and $\mathrm{OM}$ (at least $8.5 \mathrm{~cm}$ ) at P3 (Gillet and Ponge, 2002). These superficial horizons are underlain by a crumb A (organo-mineral) horizon at $\mathrm{P} 1$, and a compact $\mathrm{S}$ (mineral) horizon at $\mathrm{P} 2$ and $\mathrm{P} 3$, with an abrupt transition from organic to mineral (or organo-mineral) parts of the topsoil. Thus the humus form is a Dysmull at $\mathrm{P} 1$, and a Mor at $\mathrm{P} 2$ and $\mathrm{P} 3$. We measured soil $\mathrm{pH}$ and heavy metal contents $(\mathrm{Zn}, \mathrm{Cd}, \mathrm{Pb})$ at the three sites.

\subsection{Sampling and identification of animals}

Soil microarthropods were sampled in October 2000. At each of the three sites five soil cores $5 \mathrm{~cm}$ diameter and $10 \mathrm{~cm}$ depth, litter included, were taken with a core sampler and the fauna were extracted over ten days by the dry funnel method, using plastic funnels $20 \mathrm{~cm}$ in diameter with a $5-\mathrm{mm}$ mesh stainless steel wire net inserted in the top part and heated by a $25 \mathrm{~W}$ lamp bulb placed at $15 \mathrm{~cm}$ 
distance (Edwards and Fletcher, 1971). Care was taken that an outer space was left around the samples within the funnels and that the air circulated actively in the extraction room, in order to avoid barrier effects and too rapid desiccation of the soil, respectively (Tamura, 1976). Animals escaping the slowly drying soil were collected and preserved in $95 \%(\mathrm{v} / \mathrm{v})$ ethyl alcohol until identification. Springtails were sorted out under a dissecting microscope then mounted in chloral-lactophenol $(25 \mathrm{ml}$ lactic acid, $50 \mathrm{~g}$ chloral hydrate, $25 \mathrm{ml}$ phenol) and identified to species under a phase contrast microscope at $400 \mathrm{X}$ magnification. Gisin (1960) was used as a reference book but several more recent identification keys and diagnoses were used additionally, including Zimdars and Dunger (1994), Jordana et al. (1997), Fjellberg (1998) and Bretfeld (1999).

The sex ratio of Mesaphorura macrochaeta was determined, since males were present in our population of this otherwise parthenogenetic species (Rusek, 1976).

Centipeds, pseudoscorpions, spiders, gamasid mites, japygids, ants, staphylinids, carnivorous beetle and fly larvae were counted during the sorting process. With the exception of carabid beetles, which prey upon vagabond surface-living species, these animal groups include most predators of Collembola (Ernsting and Joosse, 1974; Walter et al., 1988; Gunn and Cherrett, 1993).

\subsection{Observation of gut contents}

After identification, gut contents from each animal mounted in chloral-lactophenol (a clearing medium) were observed under a phase contrast microscope at $400 \mathrm{X}$ magnification. Food items were identified and classified into seven categories:

- Plant material

- Fungal material

- Bacteria

- Animal remains (including exuviae)

- Holorganic humus (no recognizable plant, animal and microbial material, but without or with a weak content of mineral particles) 
- Hemorganic humus (mixing of organic matter with mineral matter, without recognizable plant, animal and microbial material)

- Empty guts

The proportion in volume of the different food items was estimated by eye in each animal and then summed up by species and site.

\subsection{Chemical analyses}

After extraction of arthropod fauna, soil samples were stored in plastic bags until analysed. The $\mathrm{pH}$ was measured electrometrically in both a 1:5 (by volume) soil:water and soil:potassium chloride $(0.1 \mathrm{M})$ suspension. Total zinc, lead and cadmium were determined after solubilization of mineral matter by hydrofluoric and perchloric acids, and after preliminary combustion of organic matter at $450^{\circ} \mathrm{C}$. Lead and cadmium were measured by atomic absorption at $283.3 \mathrm{~nm}$ and $228.0 \mathrm{~nm}$, respectively and zinc by plasma emission at $213.86 \mathrm{~nm}$. Control measurements using certified reference materials were made at the start and at the end of each run.

\subsection{Statistical treatment}

Collembolan communities were compared between the three sites by help of one-way ANOVA when raw or log-transformed data did not violate assumptions of analysis of variance. Otherwise sites were compared in pairs using non-parametric Mann-Whitney rank-sum tests (Glantz, 1997).

\section{Results}

\subsection{Chemical analyses}

Zinc was by far the most abundant heavy metal, reaching $41570 \mathrm{mg} / \mathrm{kg}$ in one topsoil sample taken at site P3. Sites P2 and P3 were richer in total $\mathrm{Zn}$ than site P1 but did not differ significantly from 
one another (Table 1). Similarly, differences between sites P2 and P3 were not significant for lead and cadmium, their contents of $\mathrm{Pb}$ and $\mathrm{Cd}$ being higher than those of $\mathrm{P} 1$.

Water $\mathrm{pH}$ did not differ between the three sites, being always near neutrality. By contrast, when measured in potassium chloride, $\mathrm{pH}$ was lower for $\mathrm{P} 1$ than for $\mathrm{P} 2$ and $\mathrm{P} 3$, indicating a decrease in exchangeable acidity in the two most polluted sites. Exchange acidity was expressed by $\delta \mathrm{pH}$, i.e. the difference between water and potassium chloride values.

\subsection{Collembolan communities}

Springtails were more abundant at P2 and P3 compared with P1, but the mean species richness, i.e. the number of species found in a sample unit, did not differ among the three sites (Table 1). The relative richness, i.e. the number of species weighted by the number of individuals found in a sample, differed significantly among the three sites, in the order $\mathrm{P} 2<\mathrm{P} 3<\mathrm{P} 1$. The total species richness, i.e. the total number of species found in the five samples taken at each site, was higher at P1 than at P2 and P3, although no significance level could be assigned to this parameter.

Changes in species composition were reflected in presence/absence of species or in changes in abundance (Table 1). The high density of collembolans at P2 and P3 was mainly due to Mesaphorura macrochaeta, the abundance of which increased significantly in the order $\mathrm{P} 1<\mathrm{P} 3<\mathrm{P} 2$. This species comprised $94 \%$ of the total community at P2, $67 \%$ at $\mathrm{P} 3$ and only $1.7 \%$ at $\mathrm{P} 1$. Friesea truncata, Parisotoma notabilis and Protaphorura armata were present at $\mathrm{P} 1$ and $\mathrm{P} 3$, not at P2, Micranurida pygmaea was present at P2, not at P1 and P3, and Lepidocyrtus cyaneus was present at $\mathrm{P} 2$ and $\mathrm{P} 3$, not at $\mathrm{P} 1$. Other species did not show significant between-site differences.

With the exception of two samples the abundance of Mesaphorura macrochaeta exhibited an increase, followed by a decrease when the $\mathrm{Zn}$ content of the topsoil increased (Fig. 1). Maximum abundance occurred between 15000 and $20000 \mathrm{mg} / \mathrm{kg}$ of Zn. Males were present at P2 and P3, with a sex ratio of 0.65 and 0.47 , respectively (Table 1 ). The presence of males could not be checked at $\mathrm{P} 1$, where only one individual, a female, was found. 


\subsection{Abundance of predators}

The total abundance of predators of Collembola was higher at P2 than at P1, the site P3 exhibiting intermediate values (Table 1). This parameter was significantly and positively correlated with the abundance of Collembola, according to Spearman rank correlation test $\left(r_{s}=0.56, P<0.05\right.$, d.f. $=$ 13).

\subsection{Diets of Collembola}

Only four species were considered for between-site comparisons, due to the need for enough replication of gut content observations, but none of these species could be used for comparing the three sites altogether. Thus only comparisons for pairs of sites will be presented (Fig. 2).

The sminthuridid Sphaeridia pumilis was present at P1 (15 individuals) and P3 (22 individuals). Strong differences were observed between the two sites in the food regime of this epigeic species. At P1 fungal material was ingested preferentially ( $47 \%$ of total food bolus volume) followed by hemorganic humus (30\%) then by holorganic humus $(23 \%)$. At P3, $90 \%$ of feeding animals had ingested hemorganic humus, only $8 \%$ having fungal material in their gut.

The isotomid Parisotoma notabilis was present at P1 (54 individuals) and P3 (49 individuals). At both sites this hemiedaphic species fed nearly exclusively on hemorganic humus (76 to $86 \%$ of total food bolus volume), but much more fungal material was eaten at P1 (8\%) compared to P3, with only $3 \%$. Bacteria and holorganic humus were present in guts of this species at P3, not at P1.

Like the two previous species the onychiurid Protaphorura armata was present at P1 (18 individuals) and P3 (21 individuals). Marked differences between these two sites were exhibited by gut contents of this euedaphic species. At P1 the dominant category was plant material (44\% of total food bolus volume), followed by holorganic humus (29\%). At P3 the dominant category was fungal material 
(44\%), followed by animal material (22\%). At P3, few guts contained plant material (7\% of total food bolus volume).

The tullbergiid Mesaphorura macrochaeta was present at P1 but at too low density (2 individuals), thus comparisons were made only between sites P2 (962 individuals) and P3 (356 individuals). At these two sites the dominant material was hemorganic humus (52\% and $73 \%$ of total food bolus volume at P2 and P3, respectively), the rest being mainly microbial (fungal and bacterial) material, but more bacteria were ingested at P2 (19\%) than at P3 (5\%).

\section{Discussion and Conclusion}

In a previous paper (Gillet and Ponge, 2002) we demonstrated that humus forms strongly differed between the less polluted site (P1), with about $4000 \mathrm{mg} / \mathrm{kg}$ of $\mathrm{Zn}$ in the topsoil, and the other two sites P2 and P3, with about 20000 and $30000 \mathrm{mg} / \mathrm{kg}$ of $\mathrm{Zn}$, respectively. In particular, at P1 the top $10 \mathrm{~cm}$ mostly comprised hemorganic material (earthworm and millipede faeces), while undecayed plant litter and roots constituted the main part of the shallow organic soil at P2 and P3. Thus quite different food and habitat conditions prevailed between P1 on the one hand, with a mull humus, and P2 and P3 on the other hand, with a mor humus. The poor humification of organic matter at the two most polluted sites was responsible for the low exchange acidity of the mor horizon (Stevenson, 1994). Despite similar pH values, the heavy metal content of the topsoil clearly differed between the three sites and was connected with the observed changes in humus form (Gillet and Ponge, 2002). Thus both direct and indirect effects of heavy metals on soil animal communities could be suspected to occur along a gradient of metal pollution (Bruus Pedersen et al., 1999).

In the present study the absence of an unpolluted control prevented us from assessing all direct as well as indirect effects of heavy metals on collembolan populations. In particular the less polluted site $\mathrm{P} 1$, with $4000 \mathrm{mg} / \mathrm{kg} \mathrm{Zn}$ in the ten top centimeters of the soil, is largely above the background level in the region considered (Schvartz et al., 1999). Nevertheless it should be noted that i) dramatic changes in humus form and vegetation were observed within the study site, all related to an increase in heavy metal toxicity (Gillet and Ponge, 2002), and ii) no proper control could be found 
within several kilometers around the smelter where land is used for agriculture and gardening (Sterckeman et al., 2000).

As a whole the collembolan community did not seem to be adversely affected by the high heavy metal content of the sites. Compared to the less polluted site $\mathrm{P} 1$, the total abundance of Collembola increased at the most polluted sites P2 and P3, reaching values higher than 100000 ind. $\mathrm{m}^{-2}$. This points to the resistance of this group as a whole to toxic effects of heavy metals (Bengtsson and Rundgren, 1988) and other environmental stresses (Ponge et al., 1993; Alvarez et al., 1999; Loranger et al., 2001). Nevertheless the observed increase in abundance was not accompanied by a corresponding increase in species richness. The total number of species collected at each site decreased from P1 to P2 and P3, and the relative richness of soil samples, i.e. the number of species weighted by the total abundance, declined tenfold from P1 to P3. This indicated that the increased abundance of the total population was due to only a few species, in agreement with results obtained in other metal-polluted sites (Bengtsson and Rundgren, 1988; Hågvar and Abrahamsen, 1990; Bruus Pedersen et al. 1999). The increase in the total abundance of Collembola observed at higher heavy metal concentration could not be ascribed to a decrease in predator pressure, as observed in acidification studies (Abrahamsen et al., 1980), since here the number of predators increased accordingly. Rather, more habitat, more food, and better protection from desiccation and frost can be suspected to occur when litter accumulates (Van Straalen et al., 1987; Takeda, 1987; Bruus Pedersen et al., 1999), explaining a higher abundance of Collembola in moder and mor, with a thick litter layer, compared to mull with a thin or no litter layer (Schaefer, 1991; Ponge et al., 1997; Loranger et al., 2001). Bengtsson and Rundgren (1988) postulated also a decrease in the population of parasites under the influence of heavy metals.

Examination of species occurrence revealed some trends which could be explained by changes in environmental conditions. Species known to live in sunny habitats, such as Brachystomella parvula, Lepidocyrtus cyaneus and Sminthurinus elegans (Ponge, 1993) were present only at sites P2 and P3, the most polluted ones where the poplar plantation had declined. The abundance of $L$. cyaneus increased from P2 to P3, following the progressive opening of the poplar canopy due to poor growth or death of planted trees (Gillet and Ponge, 2002). Some surface-living (epigeic) species were 
thus favoured by the open environment created by the lack of poplar extension, rather than by the presence of heavy metals in the soil. A similar decline in forest vegetation might probably explain the expansion of the sun species Isotoma olivacea (Ponge, 1993) in the lead-contaminated site studied by Hågvar and Abrahamsen (1990).

Despite the neutral $\mathrm{pH}$, we observed the presence of the acidophilic species Micranurida pygmaea (Hågvar and Abrahamsen, 1980; Hågvar and Abrahamsen, 1984; Ponge, 1993) at site P2. Even though not restricted to acid soils, the high abundance of Mesaphorura macrochaeta at sites P2 and P3 can be compared with its high abundance in dysmoder humus forms with a thick, compact, organic horizon (Ponge, 1993), and this species has been shown to increase under the influence of artificial acidification (Hågvar and Abrahamsen, 1980; Abrahamsen et al., 1980; Bååth et al., 1980). The bell-shaped curve observed in the distribution of this species along the pollution gradient (Fig. 1) revealed that it was (probably indirectly) favoured by an increase in the $\mathrm{Zn}$ content of the topsoil but that this favourable effect declined at the highest $\mathrm{Zn}$ concentration. A similar bell-shaped distribution of tolerant species was observed in other metal-polluted sites (Dunger, 1986; Bengtsson and Rundgren, 1988; Bruus Pedersen et al., 1999). Filser and Hölscher (1997) and Filser et al. (2000) recorded an attraction of $M$. macrochaeta to copper-polluted soils in recolonization experiments, although no correction was made for the effects of the sulphate anion. The appearance of sexual reproduction in this otherwise parthenogenetic species (Petersen, 1971) has been also reported from seashore (probably sodium-polluted) and copper-polluted environments (Petersen, 1978; Niklasson et al., 2000). This phenomenon presumably results from the inhibition or the disappearance of feminizing hormones produced by the bacteria Wolbachia, reported to occur in the parthenogenetic isotomid Folsomia candida (Vanderkerckhove et al., 1999), as well as in parthenogenetic populations of Mesaphorura macrochaeta and Paratullbergia callipygos (unpublished data). The acido-intolerant species Arrhopalites caecus and Pseudosinella alba (Ponge, 1993; Chagnon et al., 2000; Ponge, 2000b) were collected only at the less polluted site but at too low density for drawing safe conclusions about their distribution. Nevertheless overall trends in the distribution of acidophilic and acido-intolerant species point to a possible relationship between tolerance or intolerance to heavy metals and tolerance or intolerance to soil acidity. This can be explained by an increasing heavy metal toxicity in acid soils due to i) an increase in soluble metal forms when the $\mathrm{pH}$ of the soil solution decreases (Geissen et al., 
1997; Crommentuijn et al., 1997; Lee, 1999), and ii) a concentration of heavy metals in slowly decomposing litter (Laskowski and Berg, 1993).

Examination of the gut contents of species able to withstand a high heavy metal content of the topsoil (species abundant at sites P2 and P3) revealed that the organic horizon, where most heavy metals were concentrated (Balabane et al., 1999), was mostly avoided as a food source, except for Protaphorura armata. The epigeic species Sphaeridia pumilis ingested fungal material to a large extent at the least polluted site P1. At the most polluted site P3 the same species avoided this material in favour of hemorganic humus, which was present only beneath the thick organic horizon (Gillet and Ponge, 2002). It is known that fungi concentrate heavy metals in their cell walls to a great extent (Hopkin, 1994; Michelot et al., 1998) and that heavy metal-enriched food is avoided by algal-feeding springtail species (Joosse and Verhoef, 1983). Conversely, clay minerals are known to detoxify the soil from heavy metals by sorption processes (Brady and Weil, 1999). Thus the tolerance exhibited by Sphaeridia pumilis can be at least partly explained by a shift from an epigeic to an endogeic habitat and associated changed food habits. Similar conclusions can be drawn from examination of gut contents of the hemiedaphic species Parisotoma notabilis, known to feed mainly on amorphous organic matter and faecal material (Wolters, 1987; Ponge, 1991; Chen et al. 1996). The dominance of hemorganic humus in its food diet was not affected by the heavy metal content of the topsoil, although this food source was absent from the organic horizon at the most polluted sites P2 and P3. Thus $P$. notabilis just followed the distribution of its commonest (probably weakly polluted) food and shifted from surface to deeper horizons, without changing its feeding behaviour. This probably allowed this species, which is highly susceptible to heavy metal and acid pollution (Hågvar and Kjøndal, 1981; Bengtsson and Rundgren, 1988; Kopeski, 1992), to avoid high concentrations of heavy metals while being still abundant in the most polluted site.

The case of Protaphorura armata deserves a particular attention, since we observed a shift from plant-dominated to fungal-dominated material when passing from the least to the most polluted site (Fig. 2). This species is known as a root/fungal feeder (McMillan, 1975; Brown, 1985; Shaw, 1988), which adapts its diet to the availability of plant and fungal material in its immediate environment (Ponge, 2000a). It clearly ingested preferentially roots (probably from poplar) at the least polluted site 
P1, but root material (mostly from hyperaccumulating plants) was avoided at the most polluted site P3, in favour of fungi, which are known to attract this species over a large distance (Bengtsson et al., 1988b; Bengtsson et al., 1991; Bengtsson et al., 1994b). The latter organisms accumulated heavy metals, but to a lower extent than hyperaccumulating plants (Brooks, 1998). Only a minor part of hemorganic humus was found to be in the diet of this animal at both sites, but it should be pointed out that many animal remains were ingested at the most polluted site. Most of this animal material was made of its own exuviae, which probably indicates that moulting occurred at a higher rate at the most polluted site. Renewal of the gut epithelium at each moulting stage is considered as the most efficient detoxifying mechanism in Hexapoda (Humbert, 1979; Joosse and Buker, 1979; Van Straalen and Donker, 1994). Thus on the basis of our study we must consider tentatively $P$. armata (also called Onychiurus armatus in other studies) as more tolerant to heavy metals than P. notabilis and S. pumilis, which need changes in habitat and diet in order to survive in metal-polluted soils. Conclusions about the tolerance of $P$. armata towards heavy metals are supported by field studies (Bengtsson and Rundgren, 1988; Hågvar and Abrahamsen, 1990; Filser et al., 1995), although the behaviour of this species in laboratory tests did not reflect field situations (Bengtsson et al., 1983; Bengtsson et al., 1985).

Mesaphorura macrochaeta was abundant only at the two most polluted sites P2 and P3, where it comprised the bulk of the collembolan community. Unfortunately changes in food diet could not be revealed along the pollution gradient, since comparison with $\mathrm{P} 1$ was impossible. Hemorganic humus prevailed in guts from the two most polluted sites, pointing to the need for this species, known to ingest mainly mycorrhizal roots and holorganic humus in organic-rich soils (Ponge, 2000a), to feed on deeper, less-polluted horizons in order to survive heavy metal pollution. Its small size and slender shape allow it to penetrate the compact hemorganic horizon situated just beneath the organic horizon (Haarlov, 1955). We hypothesize that this small onychiurid species was less tolerant to heavy metals than $P$. armata, but that its particular adaptation to small pores and the flexibility of its food requirements allow it to live (and even thrive) in less-polluted and well-protected microenvironments. This may explain why it has been observed in high numbers in other metal-polluted sites (Filser et al., 1995). The capacity of a collembolan species to avoid metal-enriched micro-environments has been demonstrated to increase its dominance in a metal polluted soil (Tranvik and Eijsackers, 1989). 
Although not experimentally based the present results point on the importance of avoidance behaviour and ecological plasticity in the accomodation of collembolan species (including the metalsensitive Parisotoma notabilis) to metal pollution. This should be considered as an efficient behavioural mechanism, in addition to genetically fixed detoxication mechanisms (Posthuma et al., 1993; Van Straalen, 1999).

\section{Acknowledgements}

We thank the Centre National de la Recherche Scientifique (Programme Environnement, Vie et Sociétés) for financial support within a research project directed by Pr. Daniel Petit (Lille), and the Institut National de la Recherche Agronomique (Michael Gueroult, Arras) for chemical analyses.

\section{References}

Abrahamsen, G., Hovland, J., Hågvar, S., 1980. Effects of artificial acid rain and liming on soil organisms and the decomposition of organic matter. In: Hutchinson, T.C., Havas, M. (Eds.), Effects of acid precipitation on terrestrial ecosystems. Plenum Publishing Corporation, New York, pp. 341-362.

Alvarez, T., Frampton, G.K., Goulson, D., 1999. The effects of drought upon epigeal Collembola from arable soils. Agr. For. Entomol. 1, 243-248.

Bååth, E., Berg, B., Lohm, U., Lundgren, B., Lundkvist, H., Rosswall, T., Söderström, B., Wiren, A., 1980. Effects of experimental acidification and liming on soil organisms and decomposition in a Scots pine forest. Pedobiologia 20, 85-100.

Balabane, M., Faivre, D., Van Oort, F., Dahmani-Muller, H., 1999. Mutual effects of soil organic matter dynamics and heavy metals fate in a metallophyte grassland. Environ. Pollut. 105, 45-54. 
Bengtsson, G., Berden, M., Rundgren, S., 1988a. Influence of soil animals and metals on decomposition processes: a microcosm experiment. J. Environ. Qual. 17, 113-119.

Bengtsson, G., Erlandsson, A., Rundgren, S., 1988b. Fungal odour attracts soil Collembola. Soil Biol. Biochem. 20, 25-30.

Bengtsson, G., Gunnarsson, T., Rundgren, S., 1983. Growth changes caused by metal uptake in a population of Onychiurus armatus (Collembola) feeding on metal polluted fungi. Oikos 40, $216-225$

Bengtsson, G., Gunnarsson, T., Rundgren, S., 1985. Influence of metals on reproduction, mortality and population growth in Onychiurus armatus (Collembola). J. Appl. Ecol. 22, 967-978.

Bengtsson, G., Hedlund, K., Rundgren, S., 1991. Selective odor perception in the soil Collembola Onychiurus armatus. J. Chem. Ecol. 17, 2113-2125.

Bengtsson, G., Hedlund, K., Rundgren, S., 1994a. Food- and density-dependent dispersal: evidence from a soil collembolan. J. Anim. Ecol. 63, 513-520.

Bengtsson, G., Rundgren, S., 1988. The Gusum case: a brass mill and the distribution of soil Collembola. Can. J. Zool. 66, 1518-1526.

Bengtsson, G., Rundgren, S., Sjögren, M., 1994b. Modelling dispersal distances in a soil gradient: the influence of metal resistance, competition, and experience. Oikos 71, 13-23.

Brady, N.C., Weil, R.R., 1999. The nature and properties of soil, $12^{\text {th }}$ ed. Prentice Hall, Upper Saddle River, $881 \mathrm{pp}$.

Bretfeld, G., 1999. Synopses on palaearctic Collembola. II. Symphypleona. Abh. Ber. Naturkundemus. Görlitz 71, 1-318. 
Brêthes, A., Brun, J.J., Jabiol, B., Ponge, J.F., Toutain, F., 1995. Classification of forest humus forms: a French proposal. Ann. Sci. For. 52, 535-546.

Brooks, R.R., 1998. Plants that hyperaccumulate heavy metals, their role in phytoremediation, microbiology, archaeology, mineral exploration and phytomining. CAB International, Wallingford, $380 \mathrm{pp}$.

Brown, R.A., 1985. Effects of some root-grazing arthropods on the growth of sugar-beet. In: Fitter, A.H., Atkinson, D., Read, D.J., Usher, M.B. (Eds.), Ecological interactions in soil: plants, microbes and animals. Blackwell, Oxford, pp. 285-295.

Bruus Pedersen, M., Axelsen, J.A., Strandberg, B., Jensen, J., Attrill, M.J., 1999. The impact of a copper gradient on a microarthropod field community. Ecotoxicology 8, 467-483.

Chagnon, M., Hébert, C., Paré, D., 2000. Community structures of Collembola in sugar maple forests: relations to humus type and seasonal trends. Pedobiologia 44, 148-174.

Chen, B., Snider, R.J., Snider, R.M., 1996. Food consumption by Collembola from northern Michigan deciduous forest. Pedobiologia 40, 149-161.

Coughtrey, P.J., Jones, C.H., Martin, M.H., Shales, S.W., 1979. Litter accumulation in woodlands contaminated by $\mathrm{Pb}, \mathrm{Zn}, \mathrm{Cd}$ and $\mathrm{Cu}$. Oecologia 39, 51-60.

Crommentuijn, T., Doornekamp, A., Van Gestel, C.A.M., 1997. Bioavailability and ecological effects of cadmium on Folsomia candida (Willem) in an artificial soil substrate as influenced by $\mathrm{pH}$ and organic matter. Appl. Soil Ecol. 5, 261-271. 
Dunger, W., 1986. Observations on the ecological behaviour of some species of the Tullbergia krausbaueri group. In: Dallai, R. (Ed.), Proceedings of the First International Seminary on Apterygota, Siena, Italy, 13/IX-16/IX 1978. University of Siena Press, Siena, pp. 111-115.

Edwards, C.A., Fletcher, K.E., 1971. A comparison of extraction methods for terrestrial arthropods. In: Phillipson, J. (Ed.), Methods of study in quantitative soil ecology: population, production and energy flow. Blackwell, Oxford, pp. 150-185.

Ernsting, G., Joosse, E.N.G., 1974. Predation on two species of surface dwelling Collembola. A study with radio-isotope labelled prey. Pedobiologia 14, 222-231.

Filser, J., Fromm, H., Nagel, R.F., Winter, K., 1995. Effects of previous intensive agricultural management on microorganisms and the biodiversity of soil fauna. Plant Soil 170, 123-129.

Filser, J., Hölscher, G., 1997. Experimental studies on the reactions of Collembola to copper contamination. Pedobiologia 41, 173-178.

Filser, J., Wittmann, R., Lang, A., 2000. Response types in Collembola towards copper in the microenvironment. Environ. Pollut. 107, 71-78.

Fjellberg, A., 1998. The Collembola of Fennoscandia and Denmark. I. Poduromorpha. Brill, Leiden, $184 \mathrm{pp}$.

Geissen, V., Illmann, J., Flohr, A., Kahrer, R., Brümmer, G.W., 1997. Effects of liming and fertilization on Collembola in forest soils in relation to soil chemical parameters. Pedobiologia 41, 194-201.

Gillet, S., Ponge, J.F., 2002. Humus forms and metal pollution in soil. Eur. J. Soil Sci. 53 (in press).

Gisin, H., 1960. Collembolenfauna Europas. Museum d'Histoire Naturelle, Genève, 312 pp. 
Glantz, S.A., 1997. Primer of biostatistics, $4^{\text {th }}$ ed. McGraw-Hill, New York, 473 pp.

Gunn, A., Cherrett, J.M., 1993. The exploitation of food resources by soil meso- and macroinvertebrates. Pedobiologia 37, 303-320.

Haarlov, N., 1955. Vertical distribution of mites and Collembola in relation to soil structure. In: McE. Kevan, D.K. (Ed.), Soil zoology. Butterworths, London, pp. 167-179.

Hågvar, S., Abrahamsen, G., 1980. Colonisation by Enchytraeidae, Collembola and Acari in sterile soil samples with adjusted pH levels. Oikos 34, 245-258.

Hågvar, S., Abrahamsen, G., 1984. Collembola in Norwegian coniferous forest soils. III. Relations to soil chemistry. Pedobiologia 27, 331-339.

Hågvar, S., Abrahamsen, G., 1990. Microarthropods and Enchytraeidae (Oligochaeta) in naturally lead-contaminated soil: a gradient study. Environ. Entomol. 19, 1263-1277.

Hågvar, S., Kjøndal, B.R., 1981. Effects of artificial acid rain on the microarthropod fauna in decomposing birch leaves. Pedobiologia 22, 409-422.

Hasegawa, M., Takeda, H., 1995. Changes in feeding attributes of four collembolan populations during the decomposition process of pine needles. Pedobiologia 39, 155-169.

Hopkin, S.P., 1994. Effects of metal pollutants on decomposition processes in terrestrial ecosystems with special reference to fungivorous soil arthropods. In: Ross, S.M. (Ed.), Toxic metals in soilplant systems. Wiley, Chichester, pp. 303-326.

Humbert, W., 1979. The midgut of Tomocerus minor Lubbock (Insecta, Collembola): ultrastructure, cytochemistry, ageing and renewal during a moulting cycle. Cell Tissue Res. 196, 39-57. 
Joosse, E.N.G., Buker, J.B., 1979. Uptake and excretion of lead by litter-dwelling Collembola. Environ. Pollut. 18, 235-240.

Joosse, E.N.G., Verhoef, S.C., 1983. Lead tolerance in Collembola. Pedobiologia 25, 11-18.

Jordana, R., Arbea, J.I., Simón, C., Luciáñez, M.J., 1997. Fauna Iberica. VIII. Collembola Poduromorpha. Museo Nacional de Ciencias Naturales, and Consejo Superior de Investigaciones Científicas, Madrid, 807 pp.

Kopeszki, H., 1992. Veränderungen der Mesofauna eines Buchenwaldes bei Säurebelastung. Pedobiologia 36, 295-305.

Laskowski, R., Berg, B., 1993. Dynamics of some mineral nutrients and heavy metals in decomposing forest litter. Scand. J. For. Res. 8, 446-456.

Lee, J.A., 1999. The calcicole-calcifuge problem revisited. Adv. Bot. Res. 29, 1-30.

Loranger, G., Bandyopadhyaya, I., Razaka, B., Ponge, J.F., 2001. Does soil acidity explain altitudinal sequences in collembolan communities? Soil Biol. Biochem. 33, 381-393.

McMillan, J.H., 1975. Interspecific and seasonal analyses of the gut contents of three Collembola (Family Onychiuridae). Rev. Ecol. Biol. Sol 12, 449-457.

Michelot, D., Siobud, E., Doré, J.C., Viel, C., Poirier, F., 1998. Update on metal content profiles in mushrooms. Toxicological implications and tentative approach to the mechanisms of bioaccumulation. Toxicon 36, 1997-2012.

Niklasson, M., Petersen, H., Davis Parker Jr, E., 2000. Environmental stress and reproductive mode in Mesaphorura macrochaeta (Tullbergiinae, Collembola). Pedobiologia 44, 476-488. 
Petersen, H., 1971. Parthenogenesis in two common species of Collembola: Tullbergia krausbaueri (Börner) and Isotoma notabilis Schäffer. Rev. Ecol. Biol. Sol 8, 133-138.

Petersen, H., 1978. Sex-ratios and the extent of parthenogenetic reproduction in some collembolan populations. In: Dallai, R. (Ed.), Proceedings of the First International Seminar on Apterygota, Siena, Italy, 13/IX-16/IX 1978. University of Siena Press, pp. 19-35.

Petersen, H., 1994. A review of collembolan ecology in ecosystem context. Acta Zool. Fennica 195, $111-118$.

Ponge, J.F., 1991. Food resources and diets of soil animals in a small area of Scots pine litter. Geoderma 49, 33-62.

Ponge, J.F., 1993. Biocenoses of Collembola in atlantic temperate grass-woodland ecosystems. Pedobiologia 37, 223-244.

Ponge, J.F., 2000a. Vertical distribution of Collembola (Hexapoda) and their food resources in organic horizons of beech forests. Biol. Fertil. Soils 32, 508-522.

Ponge, J.F., 2000b. Acidophilic Collembola: living fossils? Contr. Biol. Lab. Kyoto Univ. 29, 65-74.

Ponge, J.F., Arpin, P., Sondag, F., Delecour, F., 1997. Soil fauna and site assessment in beech stands of the Belgian Ardennes. Can. J. For. Res. 27, 2053-2064.

Ponge, J.F., Arpin, P., Vannier, G., 1993. Collembolan response to experimental perturbations of litter supply in a temperate forest ecosystem. Eur. J. Soil Biol. 29, 141-153.

Ponge, J.F., Charnet, F., Allouard, J.M., 2000. Comment distinguer dysmoder et mor? L'exemple de la forêt domaniale de Perche-Trappe (Orne). Rev. For. Fr. 52, 23-37. 
Posthuma, L., Hogervorst, Joosse, E.N.G., Van Straalen, N.M., 1993. Genetic variation and covariation for characteristics associated with cadmium tolerance in natural populations of the springtail Orchesella cincta (L.). Evolution 47, 619-631.

Rusek, J., 1976. New Onychiuridae (Collembola) from Vancouver Island. Can. J. Zool. 54, 19-41.

Schaefer, M., 1991. Fauna of the European temperate deciduous forest. In: Röhrig, E., Ulrich, B. (Eds.), Ecosystems of the world. VII. Temperate deciduous forests. Elsevier, Amsterdam, pp. 503-525.

Schvartz, C., Denaix, L., Douay, F., Perdrix, E., Sterckeman, T., Wroblewski, A., Charbonnier, P., Ledésert, B., 1999. Pathways of transfer of $\mathrm{Pb}, \mathrm{Cd}$ and $\mathrm{Zn}$ in highly contaminated soils. In: Feyen, J., Wiyo, K. (Eds.), Modelling of transport processes in soils. Purdue University Press, West Lafayette, pp. 377-387.

Scott-Fordsmand, J.J., Krogh, P.H., Hopkin, S.P., 1999. Toxicity of nickel to a soil-dwelling springtail, Folsomia fimetaria (Collembola: Isotomidae). Ecotox. Environ. Safety 43B, 57-61.

Shaw, P.J.A., 1988. A consistent hierarchy in the fungal feeding preferences of the Collembola Onychiurus armatus. Pedobiologia 31, 179-187.

Sterckeman, T., Douay, F., Proix, N., Fourrier, H., 2000. Vertical distribution of Cd, Pb and $\mathrm{Zn}$ in soils near smelters in the North of France. Environ. Pollut. 107, 377-389.

Stevenson, F.J., 1994. Humus chemistry. Genesis, composition, reactions, $2^{\text {nd }}$ ed. Wiley, New York, $496 \mathrm{pp}$.

Takeda, H., 1987. Dynamics and maintenance of collembolan community structure in a forest soil system. Res. Popul. Ecol. 29, 291-346. 
Tamura, H., 1976. Biases in extracting Collembola through Tullgren funnel. Rev. Ecol. Biol. Sol 13, 21 34.

Tranvik, L., Bengtsson, G., Rundgren, S., 1993. Relative abundance and resistance traits of two Collembola species under metal stress. J. Appl. Ecol. 30, 43-52.

Tranvik, L., Eijsackers, H., 1989. On the advantages of Folsomia fimetarioides over Isotomiella minor (Collembola) in a metal polluted soil. Oecologia 80, 195-200.

Vandekerkhove, T.T.M., Watteyne, S., Willems, A., Swings, J.G., Mertens, J., Gillis, M., 1999. Phylogenetic analysis of the $16 \mathrm{~s}$ rDNA of the cytoplasmic bacterium Wolbachia from the novel host Folsomia candida (Hexapoda, Collembola) and its implications for wolbachial taxonomy. FEMS Microb. Lett. 180, 279-286.

Van Straalen, N.M., 1999. Genetic biodiversity in toxicant-stressed populations. Prog. Environ. Sci. 1, 195-201.

Van Straalen, N.M., Donker, M.H., 1994. Heavy metal adaptation in terrestrial arthropods: physiological and genetic aspects. Proc. Sect. Exper. Appl. Entomol. Neth. Entomol. Soc. 5, 317.

Van Straalen, N.M., Geurs, M., Van der Linden, J.M., 1987. Abundance, pH-preference and mineral content of Oribatida and Collembola in relation to vitality of pine forests in the Netherlands. In: Perry, R., Harrison, Bell, J.N.B., Lester, J.N. (Eds.), Acid rain: scientific and technical advances. Selper Limited, London, pp. 674-679.

Walter, D.E., Hunt, H.W., Elliott, E.T., 1988. Guilds or functional groups? An analysis of predatory arthropods from a shortgrass steppe soil. Pedobiologia 31, 247-260. 
Wolters, V., 1987. Untersuchungen zur Interpretierbarkeit von Darminhaltanalysen an Collembolen. Jahresb. Naturwissensch. Ver. Wuppertal 40, 10-16.

Zimdars, B., Dunger, W., 1994. Synopses on palaearctic Collembola. I. Tullbergiinae. Abh. Ber. Naturkundemus. Görlitz 68, 1-71. 


\section{Figure captions}

Fig. 1. Changes in the abundance of Mesaphorura macrochaeta according to the $\mathrm{Zn}$ content of the topsoil in the three studied sites (five replicates each).

Fig. 2. Distribution of food items found during the observation of gut contents of Sphaeridia pumilis, Parisotoma notabilis and Protaphorura armata at sites P1 (least polluted) and P3 (most polluted), and of Mesaphorura macrochaeta at sites P2 (medium polluted) and P3 (most polluted). 
Table 1 Collembolan densities (ind.m-2) and topsoil chemical data in the three investigated sites. Data are means followed by standard errors. Significant differences between sites $(P<0.05)$ are indicated by different subscript letters

\begin{tabular}{|c|c|c|c|}
\hline & P1 (490 m) & P2 (340 m) & P3 (235 m) \\
\hline $\mathrm{Zn}(\mathrm{mg} / \mathrm{kg})$ & $4166 \pm 979_{b}$ & $23344 \pm 1778 a$ & $34794 \pm 3861_{a}$ \\
\hline $\mathrm{Pb}(\mathrm{mg} / \mathrm{kg})$ & $839 \pm 165_{b}$ & $4294 \pm 226_{a}$ & $5840 \pm 1030_{a}$ \\
\hline $\mathrm{Cd}(\mathrm{mg} / \mathrm{kg})$ & $47 \pm 14_{b}$ & $202 \pm 17$ a & $192 \pm 24_{a}$ \\
\hline $\mathrm{pH}$ (water) & $6.70 \pm 0.21$ & $6.88 \pm 0.04$ & $6.88 \pm 0.07$ \\
\hline pH (potassium chloride) & $5.98 \pm 0.25 b$ & $6.42 \pm 0.06_{a}$ & $6.46 \pm 0.05 a$ \\
\hline$\delta \mathrm{pH}$ & $0.72 \pm 0.05 a$ & $0.46 \pm 0.04_{b}$ & $0.42 \pm 0.02_{b}$ \\
\hline \multicolumn{4}{|l|}{ Collembolan species (ind. m $^{-2}$ ) } \\
\hline Arrhopalites bifidus Stach, 1945 & $713 \pm 713$ & 0 & 0 \\
\hline Arrhopalites caecus (Tullberg, 1871) & $204 \pm 204$ & 0 & 0 \\
\hline Brachystomella parvula (Schäffer, 1896) & 0 & 0 & $204 \pm 125$ \\
\hline Ceratophysella denticulata (Bagnall, 1941) & 0 & $1222 \pm 861$ & 0 \\
\hline Dicyrtoma fusca (Lucas, 1842) & $204 \pm 125$ & 0 & 0 \\
\hline Dicyrtomina ornata (Nicolet, 1841) & $102 \pm 102$ & 0 & 0 \\
\hline Entomobrya nivalis (Linné, 1758) & 0 & $102 \pm 102$ & 0 \\
\hline Folsomia candida (Willem, 1902) & $509 \pm 509$ & 0 & 0 \\
\hline Friesea truncata Casagnau, 1958 & $611 \pm 407_{a, b}$ & $0_{b}$ & $5500 \pm 1730_{a}$ \\
\hline Lepidocyrtus curvicollis Bourlet, 1839 & 0 & 0 & $102 \pm 102$ \\
\hline Lepidocyrtus cyaneus Tullberg, 1871 & $\mathbf{0}_{\mathrm{c}}$ & $713 \pm 125_{b}$ & $3871 \pm 1615_{a}$ \\
\hline Lepidocyrtus lignorum (Fabricius, 1781) & $102 \pm 102$ & 0 & 0 \\
\hline Megalothorax minimus (Willem, 1900) & $306 \pm 204$ & 0 & 0 \\
\hline $\begin{array}{l}\text { Mesaphorura macrochaeta (Rusek, 1976) } \\
\text { (sex ratio males/females) }\end{array}$ & $\begin{array}{l}204 \pm 125_{c} \text { (not } \\
\text { determined) }\end{array}$ & $\begin{array}{l}104406 \pm 21473_{a} \\
(0.65 \pm 0.06)\end{array}$ & $\begin{array}{l}39318 \pm 7244_{b} \\
(0.47 \pm 0.07)\end{array}$ \\
\hline Micranurida pygmaea Börner, 1901 & $\mathrm{O}_{\mathrm{b}}$ & $3463 \pm 1351_{a}$ & $0_{b}$ \\
\hline Parisotoma notabilis (Schäffer, 1896) & $5602 \pm 1172_{a}$ & $0_{b}$ & $5195 \pm 2528 a$ \\
\hline Protaphorura armata (Gisin, 1952) & $1833 \pm 934_{\mathrm{a}, \mathrm{b}}$ & $\mathrm{O}_{\mathrm{b}}$ & $2139 \pm 985 a$ \\
\hline Pseudachorutes parvulus Börner, 1901 & 0 & $306 \pm 204$ & 0 \\
\hline Pseudosinella alba (Packard, 1873) & $204 \pm 125$ & 0 & 0 \\
\hline Sminthurinus elegans (Fitch, 1863) & 0 & $407 \pm 191$ & $306 \pm 125$ \\
\hline Sphaeridia pumilis (Krausbauer, 1898) & $1528 \pm 911$ & $204 \pm 125$ & $2241 \pm 695$ \\
\hline Total abundance (ind. $\mathrm{m}^{-2}$ ) & $12121 \pm 2980_{b}$ & $110823 \pm 22513_{a}$ & $58875 \pm 9425_{a}$ \\
\hline Mean species richness & $5.4 \pm 0.5$ & $5.0 \pm 0.6$ & $6.2 \pm 0.7$ \\
\hline Relative richness & $0.280 \pm 0.071_{a}$ & $0.028 \pm 0.008_{c}$ & $0.063 \pm 0.017_{b}$ \\
\hline Total species richness & 13 & 8 & 9 \\
\hline Number of predators (ind. $\mathrm{m}^{-2}$ ) & $7843 \pm 1746_{b}$ & $20677 \pm 3741_{a}$ & $17112 \pm 4076_{\mathrm{a}, \mathrm{b}}$ \\
\hline
\end{tabular}




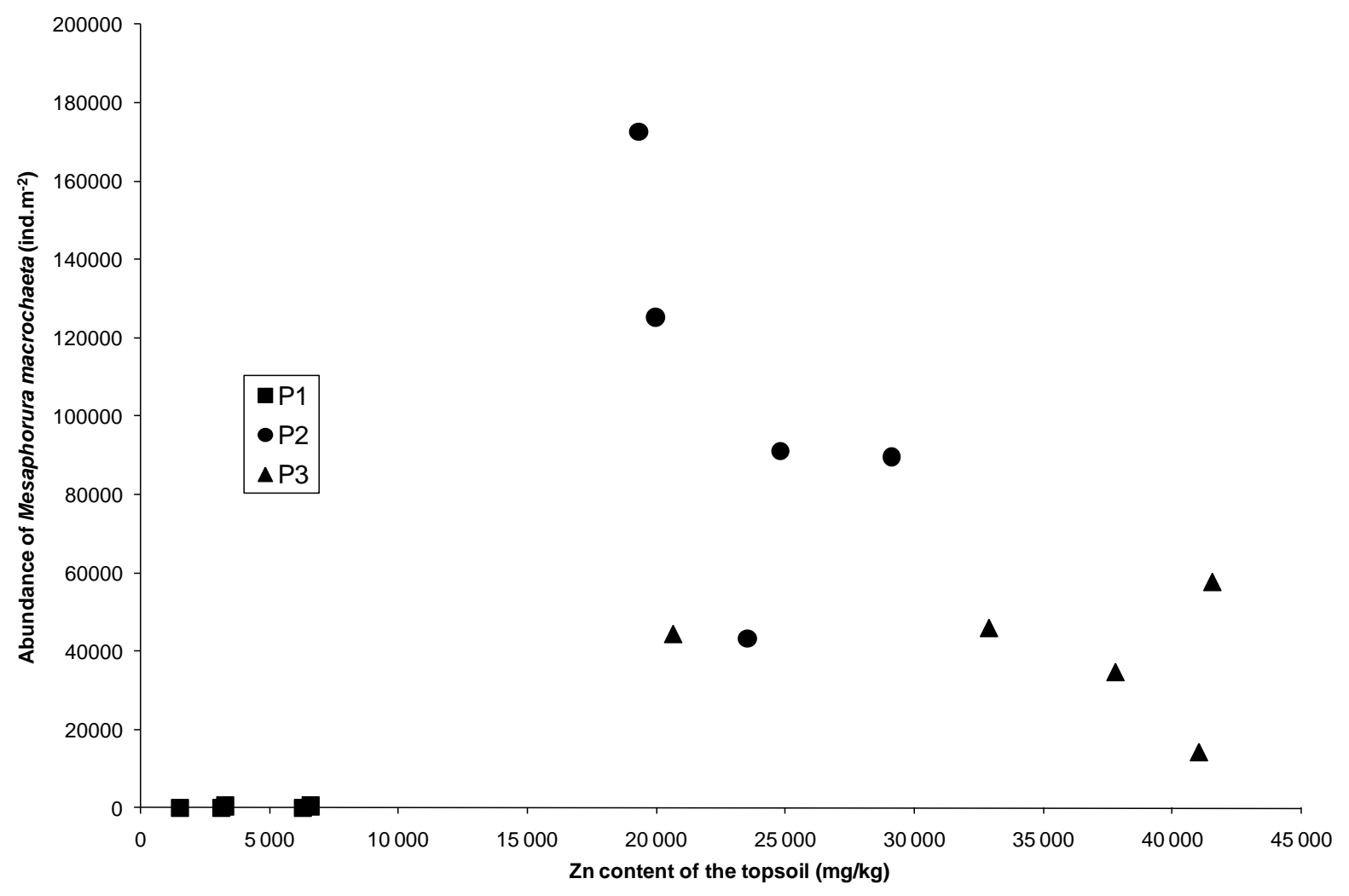

Fig. 1 

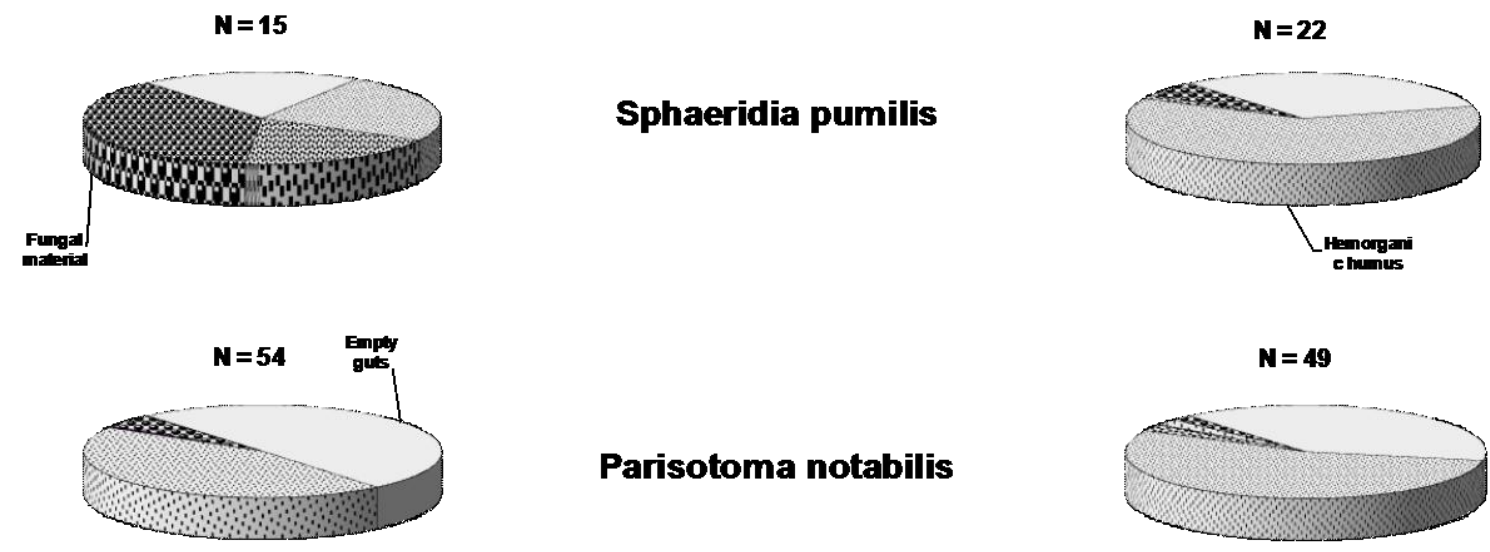

Sphaeridia pumilis

\section{Parisotoma notabilis}
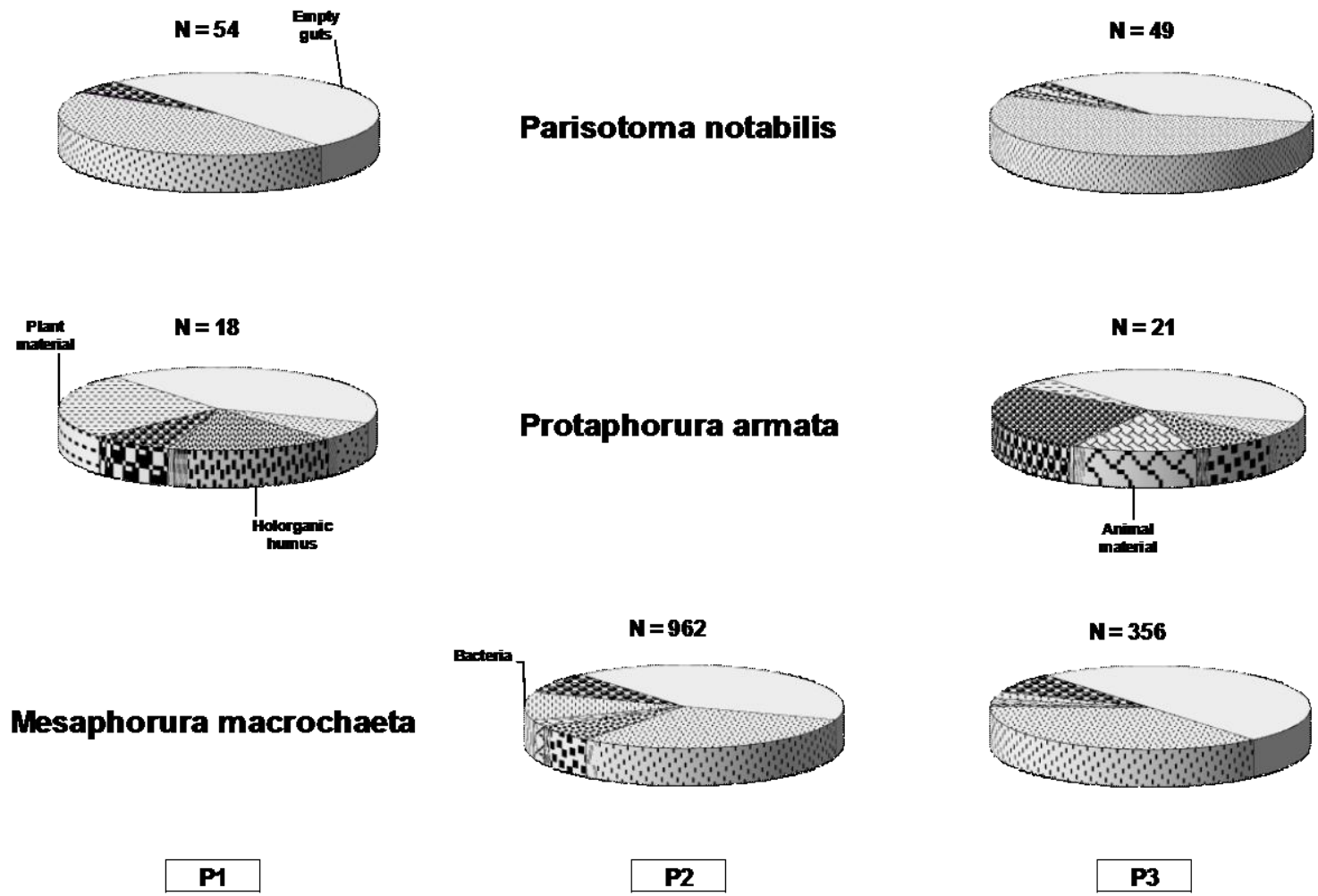

Fig. 2

\section{Protaphorura armata}

